\title{
PLASMA PROGESTERONE, ANDROSTENEDIONE AND TESTOSTERONE CONCENTRATIONS IN FREEMARTIN HEIFERS
}

\author{
N. SABA, N. F. GUNNINGHAM AND P. G. MILLAR \\ Central Veterinary Laboratory, Ministry of Agriculture, \\ Fisheries and Food, Weybridge, Surrey
}

(Received 4th December 1974)

\begin{abstract}
Summary. Plasma concentrations of testosterone, androstenedione and progesterone in freemartins, and normal cyclic and non-cyclic heifers were studied. The plasma testosterone concentrations were in general $<10 \mathrm{pg} / \mathrm{ml}$ in all animals. The mean androstenedione concentration of $28 \mathrm{pg} / \mathrm{ml}$ in 10- to 12-month-old freemartins was significantly lower than the mean of 58 to $60 \mathrm{pg} / \mathrm{ml}$ for normal 10- to 12-month-old heifers. At 24 months of age the mean androstenedione concentration in the freemartins had risen significantly to $65 \mathrm{pg} / \mathrm{ml}$.
\end{abstract}

\section{INTRODUCTION}

Although there have been extensive studies on the freemartin syndrome (for review, see Marcum 1974), only a few of these have been concerned with hormone metabolism. Short et al. (1969) found high concentrations of androstenedione and testosterone in the gonads of a highly masculinized freemartin, and suggested that endogenous production of these male hormones may have caused the masculinization. Pierrepoint et al. (1969), following their investigations on dehydroepiandrosterone and testosterone metabolism in vitro by freemartin gonads of "streak type resembling gonadal dysgenesis", concluded that the steroidogenic activities were poor but that the observed enzyme activities were of the same order as those of stromal tissue from normal heifer ovaries. Johnson et al. (1970) suggested that the plasma progesterone concentrations in 1 -year-old freemartins were significantly lower than those in normal heifers, and also found that freemartins with gonads had higher plasma concentrations of progesterone and testosterone than freemartins without gonads. However Randel et al. (1971), who found much higher plasma progesterone concentrations in 6- to 11-month-old freemartins than those reported by Johnson $e t$ al. (1970), did not observe any significant difference in plasma progesterone levels between normal heifers and freemartins of the same age. In this study, we present data on the plasma concentrations of testosterone, androstenedione and progesterone in freemartins, and normal non-cyclic and cyclic Friesian heifers.

\section{Experimental animals}

\section{MATERIALS AND METHODS}

Freemartins. Six Friesian heifers, aged 10 to 12 months, were initially identified as freemartins after clinical examination of a herd of heifers which had been 
purchased as 1-week-old calves. Digital palpation of the internal genital organs was carried out per rectum and the gross details of the broad ligaments, various portions of the genital tracts, gonads and associated structures were assessed as described by Millar \& Ras (1952). The examination of these freemartin heifers revealed that the uterine cervix was abnormal in that it was not prominent, firmly cylindrical or easy to recognize. When an attempt was made to lift the cervix between the thumb and fingers, its characteristics were those of a cord of tissue measuring about $3 \mathrm{~cm}$ in length and $0.5 \mathrm{~cm}$ in diameter. No external cervical os could be identified in relation to the anterior vagina. By tracing the cord of tissue cranially a bifurcation to tubal structures was detected. These were judged to be undifferentiated Müllerian ducts. The anterior segments of each tube had not differentiated to form palpable oviducts, and the middle portions had not developed into typical uterine horns.

The suspensory ligament (mesometrium) showed no abnormality, and the vagina was normal except for the absence of the cervix uteri and external cervical os. The gonads, which were difficult to find and identify on the anterior border of the broad ligament, were abnormal in that they were very small, measuring about $1.0 \mathrm{~cm} \times 0.5 \mathrm{~cm} \times 0.3 \mathrm{~cm}$, and did not have any of the characteristics which could be associated with developed functional ovarian tissue of heifers of this age and breed.

Subsequent cytogenetic studies showed that the proportion of XY cells in the blood of the individual freemartins was $60 \%$ in FM591, 30\% in FM593, $81 \%$ in FM607, 80\% in FM613, 2.2\% in FM630 and 6.9\% in FM693 (Pollock, 1973).

Normal heifers. Six cyclic and four non-cyclic 10- to 12-month-old Friesian heifers were studied.

Bleeding schedule. All animals were held at the laboratory for several months before the start of the studies. The freemartins were bled three times a week for 6 weeks and the normal cyclic and non-cyclic heifers were bled five times during a period of 20 days. During this period, all animals were housed indoors and received a ration of concentrates and hay. A blood sample was taken from five of the freemartins (FM591, FM593, FM607, FM613 and FM693) 1 year later, and also from an additional eleven freemartins of similar age (24 months), when the animals had been out at pasture for several weeks.

\section{Assay materials and procedures}

Phosphate-gelatin buffer, $p H 7 \cdot 0$. This contained $6.08 \mathrm{~g}$ sodium dihydrogen phosphate dihydrate, $8.75 \mathrm{~g}$ disodium hydrogen phosphate, $9.0 \mathrm{~g}$ sodium chloride, $1.0 \mathrm{~g}$ sodium azide, and $1.0 \mathrm{~g}$ gelatin per litre of solution.

Tritiated steroids. Progesterone (110 Ci $/ \mathrm{mmol})$, androstenedione (116 Ci $/ \mathrm{mmol}$ ) and testosterone $(94 \mathrm{Ci} / \mathrm{mmol}$ ) were obtained from the Radiochemical Centre, Amersham, and were dissolved in the phosphate-gelatin buffer to give 0.01 $\mu \mathrm{Ci} / 0 \cdot 1 \mathrm{ml}$ for use in the radioimmunoassays.

Charcoal suspension. This contained $500 \mathrm{mg}$ charcoal (Norit A) and $50 \mathrm{mg}$ dextran T70 in $200 \mathrm{ml}$ phosphate-gelatin buffer.

Steroid antisera. These (progesterone S49 No. 2, androstenedione S1557 No. 2 and testosterone S741 No. 2) were obtained from Dr G. Abraham, Harbor General Hospital, Torrance, California. The cross-reactions of steroids with the 
different antisera were: progesterone, 100\%; 17-hydroxyprogesterone, 90\%; 11-desoxycortisol, $90 \%$; and 11-desoxycorticosterone, $35 \%$ for antiserum S49 No. 2 (Abraham et al., 1971): androstenedione, 100\%; dehydroepiandrosterone, $25 \%$; androsterone, $7 \%$; and testosterone, $3 \%$ for antiserum S1557 No. 2 (Abraham \& Chakmakjian, 1973): testosterone, $100 \%$; $5 \alpha-$ dihydrotestosterone, $67 \%$; and androstenedione, $0.3 \%$ for antiserum $\mathrm{S} 741$ No. 2 (Coyotupa et al., 1972). Working dilutions were prepared in phosphategelatin buffer.

Radioimmunoassays. Plasma (100 $\mu \mathrm{l}$ for progesterone and $500 \mu \mathrm{l}$ for androstenedione and testosterone) was extracted with $5 \mathrm{ml}$ ether in $8 \mathrm{ml}$ glass vials stoppered with polythene caps. The vials were then placed on crushed solid $\mathrm{CO}_{2}$ for 1 to $2 \mathrm{hr}$ and the ether phase decanted from the frozen aqueous phase into clean 8-ml vials. The extract was evaporated to dryness under a stream of nitrogen at $37^{\circ} \mathrm{C}$. After complete removal of the solvent, $0.1 \mathrm{ml}$ of the appropriate antiserum was added to each vial and the mixture left at room temperature, with occasional gentle shaking, for $30 \mathrm{~min}$; this was followed by the addition of $0.1 \mathrm{ml}$ of the appropriate tritiated steroid, and, after shaking, the mixture was left at $4^{\circ} \mathrm{C}$ overnight. Unbound steroid was removed by adding $1 \mathrm{ml}$ charcoal suspension, shaking and, after $10 \mathrm{~min}$ at $4^{\circ} \mathrm{C}$, centrifuging at $500 \mathrm{~g}$ in the cold for $10 \mathrm{~min}$. The amount of bound radioactive steroid was determined on an aliquot of the clear supernatant. A set of standard non-radioactive steroids ( 0 to $200 \mathrm{pg}$ ) in phosphate-gelatin buffer was processed through the same extraction procedure and the results used to construct a standard curve. All determinations were carried out in duplicate.

\section{RESULTS}

Freemartins. The plasma concentrations of the three steroids studied over a period of 6 weeks in the six freemartins at 10 to 12 months of age are shown in Text-fig. 1.

Testosterone. Under the conditions used in these experiments, $10 \mathrm{pg}$ testosterone/ml plasma represented the minimum measurable concentration, and it can be seen from Text-fig. 1 that most of the testosterone concentrations were below $10 \mathrm{pg} / \mathrm{ml}$. Of the sixteen to eighteen plasma samples from each freemartin that were analysed, the number having testosterone values of $\geqslant 10 \mathrm{pg} / \mathrm{ml}$ and the range of these values were: FM591, eight samples, 10 to $18 \mathrm{pg} / \mathrm{ml}$; FM593, six samples, 12 to $17 \mathrm{pg} / \mathrm{ml}$; FM607, three samples, 11 to $22 \mathrm{pg} / \mathrm{ml}$; FM613, seven samples, 10 to $15 \mathrm{pg} / \mathrm{ml}$; FM630, one sample, 13 $\mathrm{pg} / \mathrm{ml}$; FM693, one sample, $14 \mathrm{pg} / \mathrm{ml}$.

Androstenedione. The results for individual freemartins plotted in Text-fig. 1 show that the plasma androstenedione concentrations varied within wide limits without any consistent pattern emerging. The mean ( \pm S.E.) androstenedione concentration of all the samples from each animal was calculated and the values are shown in Table 1. An analysis of variance showed a highly significant difference between animals $(P<0.001)$ due to the low mean value of FM607 $(11 \mathrm{pg} / \mathrm{ml})$ while the other means were in the range of 25 to $37 \mathrm{pg} / \mathrm{ml}$.

Progesterone. All values of $\leqslant 0.2 \mathrm{ng}$ progesterone $/ \mathrm{ml}$ have been plotted as such 
in Text-fig. 1. Two patterns of plasma progesterone concentrations were found. In the first, seen in FM607, FM613 and FM693, the plasma progesterone concentrations were generally very low $(\leqslant 0.2 \mathrm{ng} / \mathrm{ml})$ with occasional maximum values of 0.3 to $0.4 \mathrm{ng} / \mathrm{ml}$. In the second pattern, seen in FM591, FM593 and FM630, the low baseline levels were interrupted by surges of plasma progesterone concentrations in which values rose to 0.5 to $1.6 \mathrm{ng} / \mathrm{ml}$ plasma.

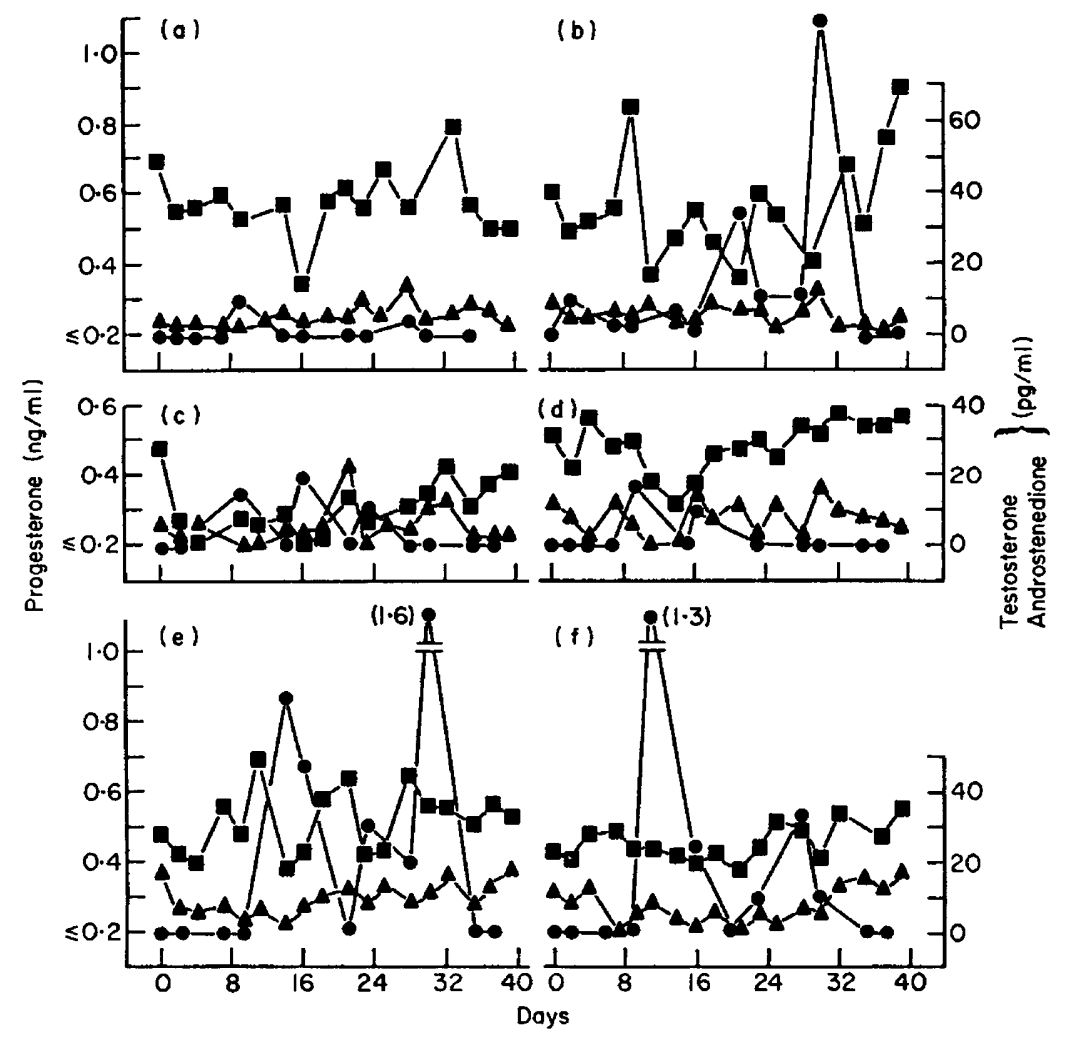

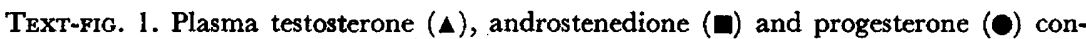
centrations of 10- to 12-month-old freemartin heifers. The overall plasma progesterone values (mean \pm S.E.) for individual freemartins were: (a) FM693, 0.091 \pm 0.032 ; (b) FM630, 0.235 \pm 0.079 ; (c) FM607, 0.118 \pm 0.048 ; (d) FM613, 0.132 \pm 0.037 ; (e) FM591, 0.359 $\pm 0 \cdot 143$; (f) FM593, 0.210 $\pm 0 \cdot 07 \overline{4}$.

When five of the freemartins were sampled again at 24 months of age, the plasma testosterone concentrations were all $<10 \mathrm{pg} / \mathrm{ml}$. Plasma androstenedione levels (Table 1) were elevated, each animal showing a higher value than any recorded at the earlier age. The mean $( \pm$ S.E.) androstenedione concentration for the five freemartins at 24 months of age $(65 \pm 6 \mathrm{pg} / \mathrm{ml})$ was significantly higher $(P<0.001)$ than the overall mean for the six animals aged 10 to 12 months $(28 \mathrm{pg} / \mathrm{ml})$. The mean $( \pm$ S.E.) plasma testosterone and androstenedione concentrations of the eleven 2-year-old freemartins not previously investigated were $<10 \mathrm{pg}$ testosterone $/ \mathrm{ml}$, and $65 \pm 9 \mathrm{pg}$ androstenedione $/ \mathrm{ml}$. 
Only one freemartin, FM607, exhibited any sign of oestrus; it remained standing when mounted.

\section{Normal heifers}

None of the four non-cyclic heifers had come into oestrus by the start of blood sampling (Day 0), but all subsequently did so; NCH689 on Day 19, NCH582 on Day 20, NCH573 on Day 22 and NCH581 on Day 33. The plasma concentrations of testosterone, androstenedione and progesterone for individual heifers are shown in Text-fig. 2. The concentrations of testosterone were consistently below $10 \mathrm{pg} / \mathrm{ml}$ in three heifers (NCH573, NCH581, and NCH582), and were 10 to $24 \mathrm{pg} / \mathrm{ml}$ in NCH689. All four heifers showed a similar pattern of plasma androstenedione concentrations during the 20-day observation period. There was no significant difference between individual heifers in the means of plasma androstenedione levels, which were 54 to 66 $\mathrm{pg} / \mathrm{ml}$ (see Table 1). The overall mean plasma androstenedione concentration for the four heifers $(58 \mathrm{pg} / \mathrm{ml})$ was significantly higher $(P<0.001)$ than the overall mean of the six 10 - to 12 -month-old freemartin heifers $(28 \mathrm{pg} / \mathrm{ml}$ ). All the plasma samples from the four heifers had progesterone concentrations of less than $1 \mathrm{ng} / \mathrm{ml}$.

Table 1. Plasma androstenedione concentrations $(\mathrm{pg} / \mathrm{ml})$ in freemartin, non-cyclic and cyclic heifers

\begin{tabular}{|c|c|c|c|c|c|}
\hline \multirow[b]{2}{*}{ Freemartins } & \multirow{2}{*}{$\begin{array}{c}\text { Animal } \\
\text { No. }\end{array}$} & \multicolumn{2}{|c|}{$\begin{array}{l}\text { Aged } 10 \text { to } 12 \text { months } \\
\quad(\text { Mean } \pm \text { S.E. })\end{array}$} & \multicolumn{2}{|c|}{$\begin{array}{c}\text { Aged } 24 \text { months } \\
\text { (single plasma sample) }\end{array}$} \\
\hline & & $\begin{array}{l}31 \pm 2(18) \\
25 \pm 1(17) \\
11 \pm 2(16) \\
28 \pm 2(18) \\
36 \pm 4(17) \\
37 \pm 3(16)\end{array}$ & $28 \pm 4^{*}$ & $\left.\begin{array}{l}79 \\
68 \\
48 \\
55 \\
76\end{array}\right\}$ & $65 \pm 6$ \\
\hline $\begin{array}{l}\text { Non-cyclic } \\
\text { heifers }\end{array}$ & $\begin{array}{l}573 \\
581 \\
582 \\
689\end{array}$ & $\begin{array}{l}54 \pm 6(5) \\
66 \pm 4(5) \\
60 \pm 5(5) \\
54 \pm 3(5)\end{array}$ & $58 \pm 3^{*}$ & E & - \\
\hline $\begin{array}{l}\text { Cyclic } \\
\text { heifers }\end{array}$ & $\begin{array}{l}566 \\
568 \\
604 \\
610 \\
635 \\
644\end{array}$ & $\begin{array}{l}67 \pm 5(5) \\
67 \pm 7(5) \\
73 \pm 4(5) \\
62 \pm 2(5) \\
53 \pm 6(5) \\
43 \pm 7(5)\end{array}$ & $61 \pm 4^{*}$ & $\begin{array}{l}\bar{z} \\
= \\
=\end{array}$ & - \\
\hline
\end{tabular}

The figures in parentheses are the number of plasma samples.

* These overall means are calculated from the means for individual heifers.

The plasma steroid concentrations for the six cyclic heifers are shown in Text-fig. 3.

Only one (CH644) had plasma testosterone levels greater than $10 \mathrm{pg} / \mathrm{ml}$ which ranged from 14 to $24 \mathrm{pg} / \mathrm{ml}$ in four samples. The patterns of plasma androstenedione levels were similar to those in the non-cyclic heifers. The mean 
plasma androstenedione concentration of the cyclic heifers was not significantly different from that of the non-cyclic heifers or that of the 24-month-old freemartins, but was significantly higher $(P<0.001)$ than that found for the 10to 12-month-old freemartins. The plasma progesterone concentrations in the cyclic heifers were typical of those of normal cyclic cows in that low concentrations $(<1 \mathrm{ng} / \mathrm{ml}$ ) were observed during the first 4 days of the cycle, followed by a rise to maximum values of 5 to $15 \mathrm{ng} / \mathrm{ml}$ during the luteal phase, and returning to the low basal levels by Days 17 to 20 of the cycle.

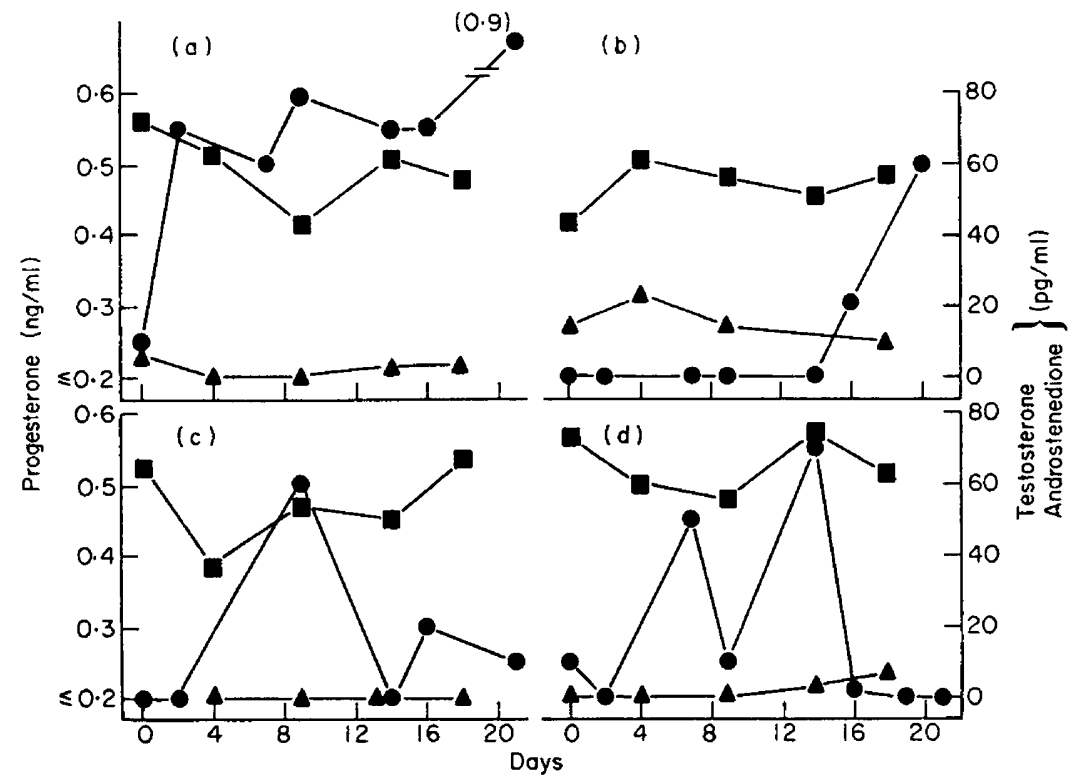

Text-Fig. 2. Plasma testosterone ( $\Delta$ ), androstenedione $(\boldsymbol{\square})$ and progesterone (O) concentrations in 10- to 12-month-old normal non-cyclic heifers. (a) NCH582; (b) NCH689; (c) NCH573; (d) NCH581.

\section{DISCUSSION}

The observations on the six 1-year-old freemartin heifers show that the plasma concentrations of the androgenic steroids were extremely low. Only $25 \%$ of the plasma samples had testosterone values $>10 \mathrm{pg} / \mathrm{ml}$, and the mean androstenedione concentrations of individual freemartins were in the range of 11 to 37 $\mathrm{pg} / \mathrm{ml}$ and were significantly lower than those for normal non-cyclic and cyclic heifers. Although the plasma progesterone values were in general low, it seems that these freemartins may be classified into two types, (1) those having consistently low plasma progesterone $(\leqslant 0.5 \mathrm{ng} / \mathrm{ml}$ ) and (2) those showing occasional surges in plasma progesterone $(>0.5 \mathrm{ng} / \mathrm{ml})$. These results show that the six freemartins had the ability to synthesize both androstenedione and progesterone, but the observation that the mean plasma androstenedione concentrations were significantly less than those found in normal heifers suggests that for this steroid the rate of secretion and/or production was lower in the freemartins than in the normal heifers. It is also apparent from the results for plasma 


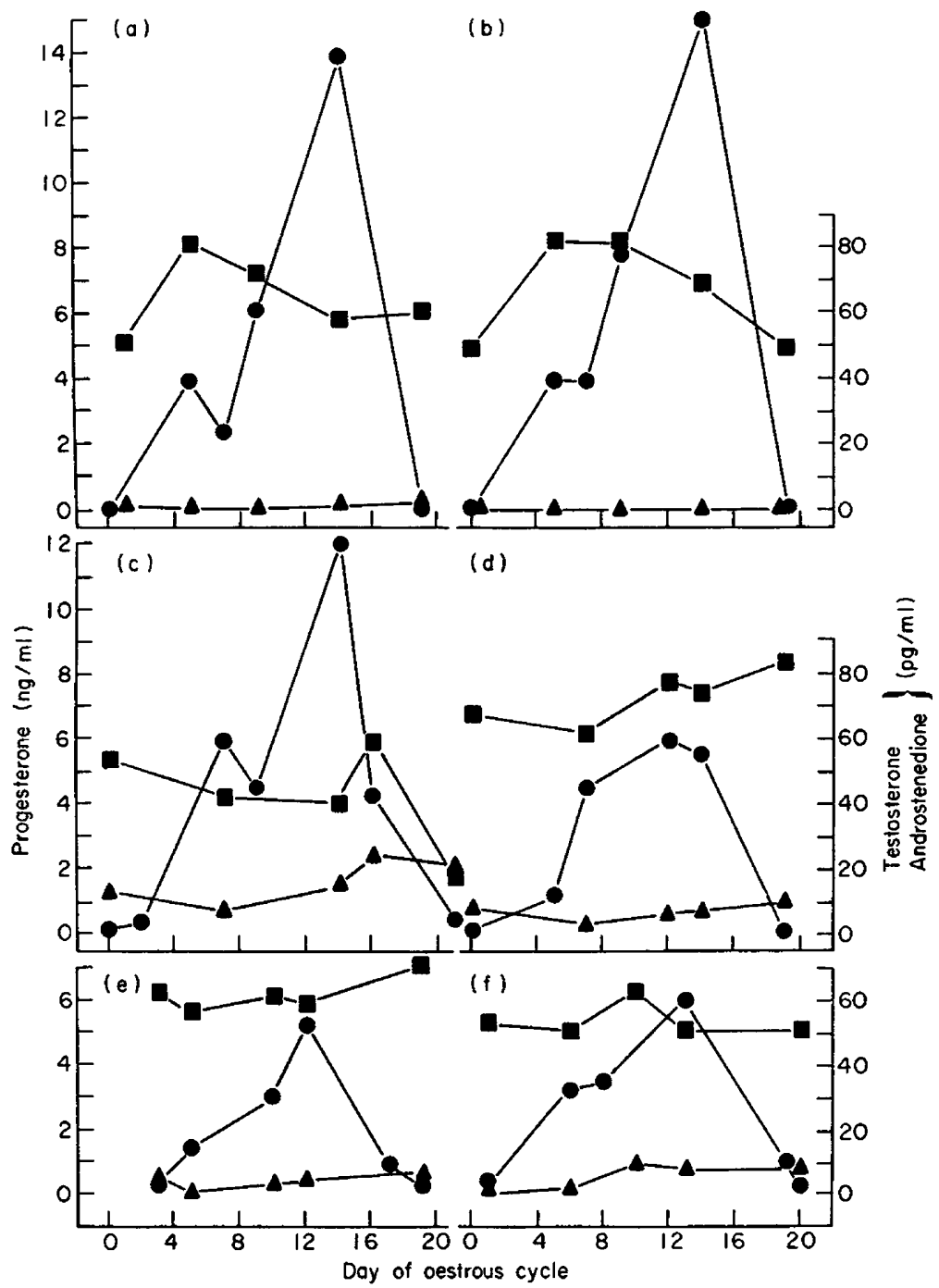

TeXT-FIG. 3. Plasma testosterone ( $\Delta$ ), androstenedione ( $\square$ ) and progesterone ( $(\bullet)$ concentrations in 10- to 12-month-old normal cyclic heifers. Day of oestrus is Day 0 . (a) CH568; (b) CH604; (c) CH644; (d) CH566; (e) CH610; (f) CH635.

progesterone that the freemartins have a capacity to produce this hormone similar to that of normal non-cyclic heifers. In freemartins showing progesterone surges, the rate of progesterone production may briefly exceed that of non-cyclic heifers.

The limited observations on 2-year-old freemartins suggest that the rate of androstenedione production had increased to normal levels as shown by an increase in plasma concentrations of this hormone which were not significantly different from those for 1-year-old normal cyclic and non-cyclic heifers. Such a rise in plasma hormone concentration was not observed in the case of testosterone. The increase in plasma androstenedione concentration is consistent 
with the findings of Short et al. (1969) in which the gonadal levels of both androstenedione and testosterone increased between 11 and 15 months of age. The reasons for this increase may not be the same in the two studies as we did not observe an increase in plasma testosterone, and the freemartin studied by Short et al. (1969) was clearly a masculine type in that it had two small testes and epididymides, whereas the six freemartins in this investigation presented anatomical features indicating an undeveloped female type.

In their studies on plasma hormone levels in 1-year-old freemartins, Johnson et al. (1970) found plasma progesterone concentrations of $8.6 \mathrm{ng} / \mathrm{ml}, 1.2 \mathrm{ng} / \mathrm{ml}$ and $0.4 \mathrm{ng} / \mathrm{ml}$ for control heifers, freemartins with gonads and freemartins without gonads respectively. The mean value of $8.6 \mathrm{ng} / \mathrm{ml}$ for control heifers is similar to the values found in cyclic heifers in this study and by Glencross $e t$ al. (1973), and our results and those of Johnson et al. (1970) demonstrate that 1year-old cyclic cows have much higher plasma progesterone concentrations than 1-year-old freemartins. If normal non-cyclic heifers are used as controls, however, our results do not show any difference between normals and freemartins, and although Randel et al. (1971) made a similar observation, the extremely high plasma progesterone values they found in 6- to 11-month-old normal heifers (mean $>4 \mathrm{ng} / \mathrm{ml}$ ) compared to those found in normal non-cyclic heifers in the present study (all values $<1 \mathrm{ng} / \mathrm{ml}$ ) makes a direct comparison difficult. The mean plasma progesterone concentrations for the six freemartins were in the range of 0.09 to $0.36 \mathrm{ng} / \mathrm{ml}$ which is comparable to the mean value of $0.4 \mathrm{ng} / \mathrm{ml}$ for freemartins without gonads (Johnson et al., 1970). We have suggested, however, that on the basis of the plasma progesterone pattern these freemartins may be divided into two groups, the first maintaining levels less than $0.5 \mathrm{ng} / \mathrm{ml}$ and the second displaying surges in progesterone concentration with values of 0.5 to $1.6 \mathrm{ng} / \mathrm{ml}$. It seems unlikely that the 'second type' of freemartin is similar to the freemartins with gonads described by Johnson $e t$ al. (1970) as the plasma testosterone levels in the 'second type' were in general less than $10 \mathrm{pg} / \mathrm{ml}$ whereas the freemartins with gonads had much higher values, with a mean concentration of $57 \mathrm{pg} / \mathrm{ml}$. Randel et al. (1971) have suggested that some of the plasma progesterone may be derived from the adrenal cortex and it is therefore possible that, under conditions of stress, surges in plasma progesterone might occur. In the present experiment, the most likely time for stress would be at the start of the bleeding schedule when the heifers were not conditioned to the experimental procedures. As, however, progesterone surges were not observed in any of the four normal non-cyclic heifers and three of the freemartins, and the earliest plasma surge occurred on Day 9 when the heifers had already been bled six times, it seems unlikely that the plasma progesterone surges in the freemartins were of adrenal origin. If these surges in plasma progesterone are produced by the gonads, this might imply the presence of luteal tissue from which progesterone release is intermittent. Further studies are required to elucidate the variable patterns of steroid hormone metabolism in freemartins.

\section{ACKNOWLEDGMENTS}

We should like to thank Dr F. Michel for making his animals available to us, 
Miss G. Nancy Hebert for the statistical analyses and Mr T. C. Martin for valuable technical assistance.

\section{REFERENCES}

Abraham, G.E. \& Chakmakjian, Z.H. (1973) Serum steroid levels during the menstrual cycle in a bilaterally adrenalectomized woman. J. clin. Endocr. Metab. 37, 581-587.

Abraham, G.E., Swerdloff, R., Tulchinsky, D. \& Odell, W.D. (1971) Radioimmunoassay of plasma progesterone. J. clin. Endocr. Metab. 32, 619-629.

Coyotupa, J., Parlow, A.F. \& Abraham, G.E. (1972) Simultaneous radioimmunoassay of plasma testosterone and dihydro-testosterone. Anal. Lett. 5, 329-340.

Glencross, R.G., Munro, I.B., Senior, B.E. \& Pope, G.S. (1973) The concentration of oestradiol-17 $\beta$, oestrone and progesterone in jugular venous plasma of cows during the oestrous cycle and early pregnancy. Acta endocr., Copenh. 73, 374-384.

Johnson, B.H., Lasater, D.B., Ewing, L.L., Turman, E.J. \& Stephens, D.F. (1970) Hormonal steroid levels in peripheral plasma of freemartins. F. Anim. Sci. 30, 321-322, Abstr.

Marcum, J.B. (1974) The freemartin syndrome. Anim. Breed. Abstr. 42, 227-242.

Millar, P.G. \& RAs, N.P. (1952) Manual of Infertility and Artificial Insemination in Cattle, pp. 42-51 and 227-237. Baillière, Tindal and Cox, London.

Pierrepoint, G.G., Stewart, J.S.S. \& Rack, J. (1969) Patterns of steroid biosynthesis in the gonads of freemartins and their male co-twins. F. Reprod. Fert. Suppl. 7, 63-72.

Pollock, D.L. (1973) A study of cytogenetics in the cattle population of Great Britain. Ph.D. thesis, Reading University.

Randel, R.D., Brown, B.L., ERB, R.E., Niswender, G.D. \& Callahan, G.J. (1971) Reproductive steroids in the bovine. II. Comparison of freemartins to fertile heifers. 7. Anim. Sci. 32, 318-326.

Short, R.V., Smith, J., Mann, T., Evans, E.P., Hallet, J., Fryer, A. \& Hamerton, J.L. (1969) Cytogenetic and endocrine studies of a freemartin heifer and its bull co-twin. Cytogenetics 8 , 369-388. 